Edunomika - Vol. 03, No. 01 (Februari 2019)

\title{
ANALISIS PENGARUH KEPEMIMPINAN, DISIPLIN KERJA, DAN LINGKUNGANN KERJA, TERHADAP KINERJA PADA FAKULTAS KEDOKTERAN UNIVERSITAS SEBELAS MARET SURAKARTA
}

\author{
Ade Atik Nurrohmah, Sri Hartono, Istiqomah \\ Fakultas Ekonomi Jurusan Manajemen \\ Universitas Islam Batik Surakarta \\ Email : adeatik15@gmail.com
}

\begin{abstract}
The aim of this study to analyze the influence Go leadership, work discipline, and work environment on employee performance at Sebelas Maret University Surakarta. This study uses quantitative methods and multiple linear regression analysis. The population in this study was 60 people. the result s of this study indicate that Leadership, Work Discipline, and Work Environment simultaneously or jointly havea positive effect on Employee Performance. Variable work discipline has a dominant influence compared to leadership variables and work environment on employeep erformance. As evidenced by the magnitude of the coefficient price for work discipline variables of 5.173 greater than the coefficient of leadership variables of 2.235 and the coefficient of the work environment of 3.835
\end{abstract}

Keywords : Leadership, Dicipline, Work environment

\section{PENDAHULUAN}

Manajemen Sumber Daya Manusia merupakan salah satu faktor terpenting dalam perusahaan Sumber daya manusia dapat memberikan kontribusi yang tidak ternilai dalam strategi pencapaian tujuan organisasi.Sumber daya manusia memiliki peran penting dalam proses produksi.Sumber Daya Manusia adalah asset perusahaan dan faktor penting untuk mewujudkan tujuan iperusahaan Peran yang utama dalam kemajuan perusahaan/ organisasi, sumber daya manusia harus dijaga atau dimanajemen seperti aset-aset perusahaan lainnya. Sebuah perusahaan dapat dikatakan menjaga karyawannya dengan baik bisa dilihat dari kinerja karyawannya (Swastika, 2015). Jika kinerja karyawan baik, maka perusahaan berhasil memanajemeni karyawannya dengan baik.

Namun ssebaliknya jjika kinerja karyawan dalam perusahaan itu tidak baik, maka perusahaan tersebut gagal dalam mengolah karyawannya. Berdasarkan latar belakang diatas maka penulis termotivasi untuk melakukan penelitian dengan judul "Analisis Kepemimpinan, Disiplin Kerja Dan Lingkungan Kerja Terhadap Kinerja Karyawan Pada Fakultas Kedokteran Universitas Sebelas Maret“.

\section{KAJIAN TEORI}

\section{Manajemen Sumber Daya Manusia}

Manajemen Sumber Daya Manusia adalah penarikan, seleksi pengembangan, pemeliharaan, dan penggunaan Sumber Daya Manusia (Handoko, 2015). 


\section{Kepemimpinan}

Kepemimpinan adalah kegiatan untuk mempengaruhi perilaku orang lain, atau seni mempengaruhi perilaku manusia baik perorangan maupun kelompok ( Miftah Thoha (2010: 9)

\section{Disiplin Kerja}

Siswanto (2001:291) mengungkapkan bahwa "disiplin kerja sebagai sikap menghormati, menghargai, dan taat pada peraturan yang berlaku baik tertulis maupun tidak tertulis serta sanggup menjalankannya. Tidak mengelak dangan sanksi-sanksi apabila melanggar tugas dan wewenang".

\section{Lingkungan Kerja}

Lingkungan Kerja adalah Kondisi Fisik dimana pekerja menempati wilayah kerja dan melakukan aktifitas pekerjaan sesuai tugas dan tanggung jawab masing-masing pekerja (Amaludin, 2015)

\section{Kinerja Karyawan}

Sedarmayanti (2011:260) mengungkapkan bahwa“ Kinerja merupakan terjemahan dari performance yang berarti hasil kerja seorang pekerja, sebuah proses manajemen atau suatu organisasi secara keseluruhan, dimana hasil kerja harus dapat ditunjukkan buktinya secara konkritdan dapat diukur

\section{METODE ANALISIS PENELITIAN}

Penulis melakukan penelitian di Fakultas Kedokteran UNS Surakarta yang beralamat di J1. Ir. Sutami No. 36A, Jebres, Surakarta.Penelitian dilakukan pada bulan Desember 2018.Dalam penelitian ini saya mengambil populasi berjumlah 60 orang dengan jumlah sampel 30 orang. Sumber data yang diperoleh berasal dari data primer dengan penyebaran kuosioner. Dalam menganalisis data menggunakan Uji Validitas, Uji Reliabilitas, Uji Asumsi Klasik, dan Analisis Regresi Linear Berganda.

\section{HASIL DAN PEMBAHASAN}

1) Dari uji validitas dengan menggunakan teknik korelasi product moment di atas dapat diketahui bahwa 30 butir pertanyaan dari variabel Kepemimpinan, Disiplin Kerja, Lingkungan Kerja, dan Kinerja Karyawan dinyatalan semuanya valid, karena nilai r yang dihasilkan lebih besar daripada critical value.

2) Dari hasil Uji Reliabilitas instrumen Kepemimpinan $\left(X_{1}\right)$ menunjukkan bahwa besarnya koefisien Alpha Cronbach adalah 0,741 > 0,60, adalah reliabel, maka butir-butir kuesioner tersebut dapat diandalkan atau dengan kata lain reliabel.

3) Reliabilitas instrumen Disiplin Kerja $\left(\mathrm{X}_{2}\right)$ menunjukkan bahwa besarnya koefisien Alpha Cronbach adalah 0,774 >0,60, adalah reliabel, maka butir-butir kuesioner tersebut dapat diandalkan atau dengan kata lain reliabel. 
4) Dari uji Run-test di iperoleh hasil outputasymp.sig (2-tailed)0,602>0,05 yang berarti menunjukkan tidak signifikan. Dengan demikian antar residual tidak terdapat korelasi, berarti lolos uji autokorelasi.

\section{KESIMPULAN DAN SARAN}

Berdasarkan hasil analisis terhadap data yang dikumpulkan, maka dapat diambil beberapa kesimpulan sebagai berikut:

1) Berdasarkan hasil perhitungan $r$ parsial dapat disimpulkan bahwa Kepemimpinan, Displin kerja dan lingkungan kerja berpengaruh positif terhadap Kinerja Karyawan, artinya semakin tinggi kepemimpinan, disiplin kerja, dan lingkungan kerja maka semakin tinggi pula kinerja karyawan Fakultas Kedokteran Universitas Sebelas Maret Surakarta.

2) Dari analisis juga diperoleh bahwa variabel Disiplin Kerjamemiliki pengaruh yang dominan dibandingkan dengan variabel Kepemimpinan dan Lingkungan Kerja terhadap kinerja karyawan. Hal tersebut dibuktikan dengan besarnya harga koefisien untuk variabel Disiplin Kerjayang lebih besar dari koefisien variabel Kepemimpinan dan koefisien variabel Lingkungan Kerja.

Berdasarkan kesimpulan-kesimpulan di atas, maka dikemukakan saran-saran sebagai berikut:

1) Untuk meningkatkan kinerja karyawan perlu didukung oleh kepemimpinan yang memadai.

2) Untuk karyawan, membiasakan berlaku tertib, menghormati pegawai lain, menjalin kerja saya yang baik dalam atu tim, sehingga dapat menciptakan budaya yang baik di tempat kerja.

3) Untuk meningkatkan kinerja karyawan perlu diberikan perhatian kepada karyawan dengan memberikan pelatihan-pelatihan khusus dari pihak swasta.

\section{DAFTAR PUSTAKA}

Sedarmayanti. 2011. Manajemen Sumber Daya Manusia. Reformasi Birokrasi dan Manajemen Pegawai Negeri Sipil. Bandung : PT Aditama

Thoha, Miftah. 2010. Kepemimpinan dan Manajemen. Devisi Buku Perguruan Tinggi. Jakarta : PT. Raja Grafindo Persada

Mangkunegaran. 2010. Manajemen Sumber Daya Manusia . Bandung : PT. Grahavindo jaya

Almustofa, Resa (2014), "Pengaruh Lingkungan Kerja, Motivasi Kerja, Disiplin Kerja Terhadap Kinerja Pegawai,” Skripsi. Semarang: Universitas Diponogoro.

Roymon, Hezkia Efrid (2014), "Pengaruh Kepemimpinan Camat Terhadap Disiplin Kerja Pegawai di Kantor Camat Kabupaten Kutai Barat," eJurnal Pemerintahan Integratif, Vol. 2, No. 3.

Mangkunegaran. 2015. Manajemen Sumber Daya Manusia . Bandung : PT. Grahavindo jaya 
Ade Atik Nurrohmah, dkk / Edunomika Vol. 03, No. 01 (Februari 2019)

Dubrin Andrew J., 2008. Leadership (Terjemahan), Edisi Kedua, Prenada Media, Jakarta.

Ghozali, imam,2001. Aplikasi Analisis Multivariate dengan Program SPSS, Badan Penerbit: Unversitas Diponegoro Semarang.

Farid Yuli, 2011. Pengaruh Motivasi Kerja Kepemimpinan dan Budaya Organisasi terhadap Kinerja Karyawan (Studi Kasus) di PDAM Eks karesidenan Surakarta. 